\title{
Prevalensi Tanda dan Gejala serta Keterlibatan Tim Multidispliner dalam Perawatan Paliatif Pasien Leukemia Anak di Rumah Sakit Umum Pusat Dr. Sardjito
}

Samalalita Rahmatina, ${ }^{1}$ Sri Mulatsih, ${ }^{2}$ Eggi Arguni, ${ }^{2}$ Sudadi ${ }^{3}$

${ }^{1}$ Program Studi Pendidikan Dokter, ${ }^{2}$ Departemen Ilmu Kesehatan Anak, ${ }^{3}$ Departemen Anestesi Universitas Gadjah Mada/RSUP Dr. Sardjito, Yogyakarta

Latar belakang. Perawatan paliatif pada anak masih jarang diteliti terutama di negara berkembang seperti Indonesia. Salah satu kategori pasien yang memerlukan perawatan paliatif adalah anak dengan kanker. Leukemia merupakan kanker dengan prevalensi terbesar pada anak. Tujuan. Mengetahui karakteristik, prevalensi tanda dan gejala, serta keterlibatan tim multidispliner dalam perawatan paliatif pasien leukemia anak di RSUP Dr. Sardjito.

Metode. Desain penelitian adalah cross sectional menggunakan data sekunder berupa rekam medis pasien berusia kurang dari 18 tahun yang didiagnosis leukemia pada tahun 2015 di RSUP Dr. Sardjito.

Hasil. Empat puluh enam pasien anak dengan leukemia dianalisis. Sebanyak 34 pasien merupakan pasien leukemia limfoblastik akut (LLA) dan 12 sisanya merupakan pasien leukemia mieloblastik akut (LMA), 20 pasien berusia 1-4 tahun, dan 26 pasien berjenis kelamin perempuan. Sepuluh pasien meninggal, 18 pasien sembuh atau telah selesai menjalani terapi, dan 18 pasien lainnya tanpa keterangan sehingga disimpulkan masih menjalani terapi. Tanda dan gejala dengan prevalensi tertinggi adalah demam ( 40 pasien), nyeri (38 pasien), mual (32 pasien), dan muntah (27 pasien). Fase induksi memiliki prevalensi tanda dan gejala tertinggi dibanding fase lainnya. Tiga kelompok tenaga kesehatan yang selalu terlibat dalam perawatan paliatif adalah residen anak/dokter spesialis anak/konsultan onkologi anak, perawat, dan dokter spesialis anestesi.

Kesimpulan. Fase induksi memiliki prevalensi tanda dan gejala tertinggi dibanding fase lain sehingga memerlukan perawatan paliatif suportif lebih banyak. Sari Pediatri 2021;23(3):185-90

Kata kunci: perawatan paliatif, leukemia, anak

\section{Sign and Symptom Prevalence and Multidisciplinary Team Involvement in Palliative Care on Childhood Leukemia in Sardjito Hospital}

Samalalita Rahmatina, ${ }^{1}$ Sri Mulatsih, ${ }^{2}$ Eggi Arguni, ${ }^{2}$ Sudadi ${ }^{3}$

Background. Palliative care on children is rarely researched especially in developing countries such as Indonesia. Children with cancer are one of the groups that need palliative care. In this case, leukemia is the most prevalent cancer happening during childhood. This study on palliative care on children becomes important due to its difference from palliative care done on adults.

Objective. The objectives of this study are to determine the characteristics, sign and symptoms prevalence, sign and symptoms frequency, and multidisciplinary team involved in palliative care to childhood leukemia patient in dr. Sardjito Hospital.

Methods. This was a retrospective-descriptive study with cross sectional design using secondary data from medical records of the patient under 18 years old diagnosed with leukemia in 2015 in dr. Sardjito Hospital.

Result. 48 patients from all 98 patients diagnosed with childhood leukemia in 2015 had their data taken. Since 2 patients did not undergo chemotherapy, there were only 46 patients that could be analyzed. 34 patients were acute lymphoblastic leukemia patients and 12 patients were acute myeloblastic leukemia, 20 patients were 1-4 years old, 26 patients were girls. 10 patients died, 18 patients recovered or had finished undergoing therapy, and 18 other patients were without information so it was concluded that they were still undergoing therapy. The most prevalent sign and symptoms were fever ( 40 patients), pain (38 patients), nausea (32 patients), and vomiting (27 patients). The induction phase had the highest signs and symptoms prevalence compared to other phases. Pediatric residents/pediatrics/pediatrics consultants, nurse, and anesthesiologists were always involved in palliative care to children.

Conclusion. The induction phase has the highest sign and symptoms prevalence compared to other phases so palliative care is needed in this phase. Sari Pediatri 2021;23(3):185-90

Keywords:: palliative care, leukemia, child

Alamat korespondensi: Samalalita Rahmatina, Jalan Kaliurang Km 10 Gondangan, Sardonoharjo, Ngaglik, Sleman, Yogyakarta. E-mail: samalalita10@gmail.com 
N on communicable diseases ( $N C D$ s) merupakan salah satu target dalam rincian sustainable development goals, di mana penyebab kematian kedua terbesar karena NCDs adalah kanker. ${ }^{1}$ Kemajuan dalam ilmu pengobatan kanker anak telah berhasil meningkatkan angka ketahanan hidup 5 tahun hingga mencapai 80 persen, tetapi kanker masih menjadi penyebab kematian kedua terbesar setelah kecelakaan pada anak berusia 5 hingga 14 tahun. $^{2}$ Kanker yang paling umum terjadi pada anak adalah leukemia. ${ }^{3}$ Delapan puluh empat persen anak dengan kanker berada di negara berkembang yang memiliki angka kematian akibat kanker yang lebih tinggi bila dibandingkan negara maju. Hal tersebut dikarenakan frekuensi kematian akibat penyakit menular dan malnutrisi yang lebih tinggi dan tidak tersedianya teknologi diagnosis dan tata laksana di negara berkembang. ${ }^{4}$

Tata laksana yang semakin berkembang berdampak pada kualitas hidup pasien. Anak yang tetap diberikan kemoterapi hingga saat kematiannya memiliki kualitas hidup lebih rendah jika dibandingkan dengan anak yang keluarganya memahami bahwa tata laksana lebih lanjut akan sia-sia dan menerima dilakukannya perawatan paliatif. ${ }^{5}$ Perawatan paliatif adalah perawatan total secara aktif terhadap tubuh, pikiran, dan jiwa anak disertai pemberian dukungan kepada keluarga sejak diagnosis pertama kali ditegakkan dan terus berlanjut baik ketika anak mendapat terapi kuratif maupun tidak. ${ }^{6}$

Rumah Sakit Umum Pusat Dr. Sardjito merupakan salah satu dari 5 rumah sakit pelopor perawatan paliatif di Indonesia. ${ }^{7}$ Penelitian ini bertujuan mengetahui karakteristik, prevalensi tanda dan gejala, dan keterlibatan tim multidispliner dalam perawatan paliatif pasien leukemia anak di RSUP dr. Sardjito.

\section{Metode}

Penelitian ini merupakan penelitian observasional deskriptif dengan rancangan penelitian potong lintang (cross-sectional) secara retrospektif menggunakan data sekunder berupa rekam medis pasien leukemia anak di Instalasi Kesehatan Anak (INSKA) RSUP Dr. Sardjito, Yogyakarta. Data diambil dari catatan rekam medis pasien berusia kurang dari 18 tahun yang didiagnosis leukemia di tahun 2015 oleh dokter di INSKA RSUP Dr. Sardjito dan dirawat antara Januari 2015 hingga
Juni 2017. Rekam medis yang tidak lengkap, serta pasien yang dropout atau meninggal sebelum menjalani kemoterapi dieksklusi. Variabel yang diteliti adalah tipe kanker, jenis kelamin, usia, tempat tinggal, prevalensi tanda dan gejala, tim multidisipliner yang terlibat, serta luaran klinis pada rekam medis terakhir. Penelitian ini telah disetujui oleh Komite Etik FK UGM - RSUD dr. Sarjito (KE/FK/1258/EC/2017).

\section{Hasil}

Empat puluh delapan dari 98 pasien yang didiagnosis leukemia akut pada tahun 2015 di RSUP Dr. Sardjito diambil datanya. Dua orang dieksklusi karena tidak mendapatkan kemoterapi. Data karakteristik tertera pada Tabel 1. Rerata usia 46 pasien adalah $6,46 \pm 4,32$ tahun dengan nilai tengah 5 tahun, pasien paling muda berusia 1 tahun dan paling tua 16 tahun. Jumlah pasien leukemia limfoblastik akut (LLA) lebih banyak dibandingkan leukemia mieloblastik akut (LMA) (34 berbanding 12). Sebagian besar pasien berasal dari luar Daerah Istimewa Yogyakarta (DIY), yaitu 37 pasien. Jumlah pasien berdasarkan jenis kelamin cukup berimbang, pasien laki laki berjumlah 20, dan perempuan 26 pasien.

Nyeri merupakan gejala dengan prevalensi tertinggi pada LLA (30 dari 34 pasien). Tanda dan gejala yang ditemukan pada pasien LLA adalah demam, mual, muntah, sesak napas, dan konstipasi. Tidak ada pasien yang terdiagnosis depresi.

Seluruh pasien LMA sebanyak 12 orang mengeluhkan demam. Tanda dan gejala pada LMA adalah mual, muntah, nyeri, dan sesak napas. Tidak ada pasien yang mengeluhkan konstipasi maupun terdiagnosis depresi pada LMA.

Data prevalensi tanda dan gejala kemudian dianalisis berdasarkan fase terjadinya sesuai dengan protokol tata laksana LLA tahun 2016 dan protokol tata laksana LMA tahun 2017 di RSUP Dr. Sardjito (Tabel 2). Nyeri dan demam terlihat bahwa prevalensi cukup tinggi terutama di fase induksi dan maintenance I pada LLA serta fase induksi I pada LMA. Sesak napas hanya dikeluhkan saat fase induksi dan maintenance I pada LLA dan fase induksi I pada LMA. Baik mual maupun muntah memiliki prevalensi tertinggi pada fase induksi baik pada LLA dan fase induksi I pada LMA. Konstipasi hanya dikeluhkan oleh pasien LLA risiko tinggi pada fase induksi. 
Tiga tenaga kesehatan yang selalu terlibat dalam perawatan pasien leukemia anak adalah residen anak/ dokter spesialis anak/konsultan kanker anak, perawat, dan dokter spesialis anestesi. Keterlibatan terbanyak kedua adalah ahli gizi diikuti rohaniawan. Selanjutnya dengan keterlibatan di bawah 20\% secara berurutan yaitu fisioterapis, rehabilitasi medis, psikolog, dokter jiwa dan tim nyeri (Tabel 3).

Dari seluruh 46 pasien, 10 pasien meninggal, 18 pasien sembuh atau telah selesai menjalani terapi, dan 18 pasien lainnya tanpa keterangan sehingga disimpulkan masih menjalani terapi. Sepuluh orang yang meninggal tersebut terdiri dari 3 pasien LMA dan 7 pasien LLA. Dari 10 pasien yang meninggal, 6 pasien meninggal saat fase induksi, 2 pasien meninggal saat fase maintenance, dan 2 pasien lainnya meninggal setelah drop out dari pengobatan. Penyebab kematiannya adalah 4 pasien meninggal karena syok sepsis, 2 pasien karena perdarahan intrakranial, 2 pasien karena tumor lysis syndrome, 1 pasien karena perdarahan paru, dan 1 pasien karena meningitis bakteri.

Tabel 1. Karakteristik sampel

\begin{tabular}{lc}
\hline Karakteristik & Jumlah $(\%, \mathrm{~N}=46)$ \\
\hline Jenis kanker & \\
LLA & $34(73,9)$ \\
Risiko standar & $17(50)$ \\
Risiko tinggi & $17(50)$ \\
LMA & $12(26,1)$ \\
Usia (tahun) & \\
$<1$ & $0(0)$ \\
$1-4$ & $20(43,5)$ \\
$5-9$ & $16(34,8)$ \\
$10-14$ & $5(10,9)$ \\
$15-18$ & $5(10,9)$ \\
Jenis kelamin & \\
Laki-laki & $20(43,5)$ \\
Perempuan & $26(56,5)$ \\
Alamat/tempat tinggal & \\
Luar Provinsi DIY & $37(80,4)$ \\
Provinsi DIY: & $4(8,7)$ \\
Kulonprogo & \\
Bantul & $3(6,5)$ \\
Sleman & $2(4,3)$ \\
Yogyakarta & $0(0)$ \\
Gunungkidul & $0(0)$ \\
\hline & \\
\hline
\end{tabular}

\section{Pembahasan}

Telah dilakukan perawatan paliatif pada 46 pasien sesuai dengan Keputusan Menteri Kesehatan nomor 812/ Menkes/SK/VII/2007, yaitu: penatalaksanaan nyeri, penatalaksanaan keluhan fisik lain, asuhan keperawatan, dukungan psikologis, dukungan sosial, dukungan kultural dan spiritual, dukungan persiapan dan selama masa berkabung (bereavement). ${ }^{8}$ Pada penelitian ini ditemukan bahwa demam memiliki prevalensi tertinggi yang dikeluhkan oleh 40 pasien LLA maupun LMA. Demam sendiri merupakan salah satu manifestasi klinis yang terjadi pada 53\% pasien leukemia anak di awal diagnosis. ${ }^{9}$ Demam berkepanjangan ( $>2$ minggu) tanpa penyebab jelas merupakan tanda dan gejala umum kanker dan diasosiasikan dengan leukemia dan limfoma. ${ }^{10}$ Demam juga dapat terjadi karena keadaan imunosupresi pada pasien leukemia, 102 dari 149 kejadian demam pada leukemia akut disebabkan oleh infeksi. ${ }^{11}$ Injeksi vincristine yang digunakan pada fase maintenance I pada LLA dapat menyebabkan demam bila tidak disertai pemberian kortikosteroid. ${ }^{12}$ Pada penelitian yang dilakukan oleh Rashidy $\mathrm{dkk},{ }^{13}$ seluruh pasien berjumlah 25 orang yang diberi mercaptopurine pada fase maintenance mengalami demam neutropenia. Mercaptopurine digunakan dalam fase maintenance I dan II penanganan pasien LLA. Hal tersebut dapat menjelaskan tingginya prevalensi demam pada fase induksi dan maintenance I pada LLA serta fase induksi I pada LMA.

Pada leukemia akut anak, nyeri pada tulang merupakan salah satu manifestasi klinis yang biasa terjadi ketika sumsum tulang semakin melebar karena akumulasi leukosit abnormal. ${ }^{14}$ Nyeri juga dapat terjadi saat prosedur aspirasi sumsum tulang atau karena obat obatan yang digunakan saat kemoterapi seperti methotrexate, cytarabine, L-asparaginase, dan vincristine. ${ }^{15,16}$ Glukokortikoid sebagai obat kemoterapi juga dapat menyebabkan toksisitas tulang dan diasosiasikan dengan nyeri parah pada tulang. ${ }^{17}$ Obatobatan tersebut terdapat dalam protokol tata laksana LLA tahun 2016 sehingga menjelaskan tingginya prevalensi nyeri pada LLA dibanding LMA, terutama pada fase induksi dan maintenance $\mathrm{I}$.

Mual dan muntah terlihat cukup tinggi pada fase induksi I LMA yang melibatkan obat kemoterapi daunorubicin dan cytarabine. Kedua obat tersebut diketahui menyebabkan emesis pada 30\%-90\% pasien. ${ }^{18}$ 
Opiod digunakan untuk meredakan nyeri pada pasien kanker dan diketahui menyebabkan mual pada dua pertiga pasien serta setengahnya mengalami muntah, tetapi toleransi terhadap efek mual muntah pada opioid dapat terjadi dan biasanya gejala berhenti setelah 1 minggu. ${ }^{19}$

Pasien yang mendapat kombinasi vincristine dan opioid berisiko mengalami konstipasi karena kedua obat tersebut dapat memperlambat motilitas kolon. ${ }^{20}$ Konstipasi terjadi pada $40-95 \%$ pasien yang menerima opioid dan umumnya tidak terjadi toleransi terhadap konstipasi karena opioid. ${ }^{19}$ Konstipasi hanya dikeluhkan oleh pasien LLA risiko tinggi pada fase induksi yang menggunakan vincristine sebagai salah satu obat kemoterapinya dan opioid untuk meredakan nyeri yang tinggi pada fase induksi.

Sesak napas dapat terjadi karena efek respiratory distress pada opioid, tetapi hal tersebut jarang terjadi dengan penggunaan dan titrasi opioid yang baik. ${ }^{19}$ Sesak napas hanya dikeluhkan saat fase induksi dan maintenance I pada LLA dan fase induksi I pada LMA. Ketiga fase tersebut merupakan fase dengan prevalensi nyeri tertinggi.

Pada penelitian ini ditemukan bahwa dokter ahli anestesi selalu terlibat pada perawatan paliatif leukemia anak. Hal tersebut disebabkan pemberian methotrexate secara intratekal merupakan prosedur invasif yang memerlukan ketenangan pasien sehingga dibutuhkan sedasi tidak hanya sedasi lokal, tetapi sedasi sedang hingga berat. Tim nyeri hanya terlibat 1 kali, hal ini mungkin disebabkan karena keterlibatan tim nyeri hanya terjadi ketika pasien mengalami nyeri dengan skala lebih dari 6 . Tim Nyeri di rumah sakit terdiri dari komponen Dokter Spesialis Anestesi dan Perawatan Intensif, Dokter Spesialis Neurologi, Dokter Spesialis Penyakit Dalam dan Dokter Spesialis Anak. Peran Tim Nyeri secara umum adalah meningkatkan kualitas pelayanan manajemen nyeri pada pasien

Ahli gizi merupakan tenaga kesehatan kedua yang memiliki keterlibatan paling banyak dan mengindikasikan pentingnya masalah nutrisi. Pada penelitian yang dilakukan di Lebanon tahun 2016, anak yang kekurangan gizi berpeluang lebih tinggi memiliki luaran klinis yang lebih buruk seperti kematian dan atau kekambuhan, peluang tersebut lebih tinggi lagi pada anak stunting. ${ }^{21}$ Rohaniawan menempati peringkat selanjutnya komponen yang terlibat setelah ahli gizi. Seorang rohaniawan berkontribusi terhadap masalah kritis, seperti penderitaan spiritual pasien/keluarga, meningkatkan komunikasi antara keluarga dengan tenaga kesehatan, dan menyediakan ritual terkait dukungan spiritual baik kepada keluarga maupun tenaga kesehatan. ${ }^{22}$

Pada penelitian ini, 6 dari 10 pasien meninggal saat fase induksi. Gupta dkk ${ }^{23}$ menemukan bahwa kematian terkait pengobatan terjadi pada 9,3\% pasien LLA anak, $59 \%$ dari kematian tersebut terjadi saat fase induksi. Menurut Martín-Trejo dkk, ${ }^{24}$ penyebab kematian

Tabel 2. Prevalensi tanda dan gejala berdasarkan fase

\begin{tabular}{lcccccc}
\hline Jenis kanker dan fase & Nyeri & Sesak napas & Mual & Muntah & Konstipasi & Demam \\
\hline LLA risiko standar & $\mathrm{n}=16$ & $\mathrm{n}=3$ & $\mathrm{n}=12$ & $\mathrm{n}=10$ & & $\mathrm{n}=16$ \\
Induksi & 14 & 2 & 8 & 3 & & 9 \\
Konsolidasi & 4 & 0 & 7 & 3 & & 8 \\
Maintenance I & 14 & 1 & 3 & 3 & & 9 \\
Maintenance II & 9 & 0 & 3 & 2 & & 4 \\
LLA risiko tinggi & $\mathrm{n}=14$ & $\mathrm{n}=4$ & $\mathrm{n}=10$ & $\mathrm{n}=9$ & $\mathrm{n}=2$ & $\mathrm{n}=12$ \\
Induksi & 12 & 2 & 6 & 6 & 2 & 9 \\
Konsolidasi & 9 & 0 & 4 & 5 & 0 & 4 \\
Reinduksi & 6 & 0 & 1 & 1 & 0 & 3 \\
Maintenance I & 10 & 2 & 3 & 1 & 0 & 8 \\
Maintenance II & 3 & 0 & 1 & 0 & 0 & 2 \\
LMA & $\mathrm{n}=8$ & $\mathrm{n}=3$ & $\mathrm{n}=10$ & $\mathrm{n}=8$ & & $\mathrm{n}=12$ \\
Induksi I & 6 & 3 & 9 & 6 & & 7 \\
Induksi II & 4 & 0 & 4 & 3 & & 5 \\
Konsolidasi & 3 & 0 & 2 & 1 & & 5 \\
\hline
\end{tabular}


Samalalita Rahmatina dkk: Prevalensi tanda dan gejala serta keterlibatan tim multidispliner dalam perawatan paliatif pasien leukemia

Tabel 3. Keterlibatan tim multidisipliner

\begin{tabular}{lcc}
\hline Profesi & Jumlah & $(\%)$ \\
& $\mathrm{N}=46$ & \\
\hline Residen pediatrik/ dokter spesialis anak/ konsultan anak & 46 & 100 \\
Perawat & 46 & 100 \\
Dokter spesialis anestesi & 46 & 100 \\
Ahli gizi & 28 & 60,9 \\
Rohaniawan & 21 & 45,7 \\
Fisioterapis & 8 & 17,4 \\
Rehabilitasi medis & 7 & 15,2 \\
Psikolog & 3 & 6,5 \\
Dokter spesialis kedokteran jiwa & 1 & 2,2 \\
Tim nyeri & 1 & 2,2 \\
\hline
\end{tabular}

utama satu tahun pertama terapi pada LLA adalah infeksi, kemudian perdarahan, dan yang ketiga adalah syok sepsis dan hipovolemik. Sebagian besar kematian terkait pengobatan terjadi saat kejadian neutropenia dan limfopenia yang berulang dan berkepanjangan karena obat yang bersifat menekan sistem imun dan sitotoksik. Keadaan ini dapat juga karena leukemia itu sendiri menghambat perbaikan sumsum tulang saat terapi induksi, terutama pada pasien yang memiliki respon lambat. Penggantian prednison dengan deksametason saat kemoterapi induksi serta paparan yang lebih lama dan berulang terhadap deksametason saat fase maintenance dapat meningkatkan kejadian infeksi letal. ${ }^{25}$

Menurut Wang $\mathrm{dkk},{ }^{26}$ terdapat variasi dalam ketahanan hidup pasien berdasar usia pada pasien anak LLA. Luaran terburuk terjadi saat usia diagnosis bayi ( $<1$ tahun) dan luaran terbaik terjadi saat usia diagnosis 1-4 tahun. Mereka yang usia diagnosis 1-4 tahun, 5-9 tahun, 10-14 tahun, dan 15-19 tahun masing masing $82 \%$, 75\%, 57\%, dan 32\% kemungkinan lebih kecil untuk meninggal dibanding anak yang didiagnosis LLA saat usia bayi. Sementara pada pasien LMA, ditemukan bahwa usia diagnosis bayi dan 1-4 tahun memiliki prognosis paling buruk. Pada penelitian ini, dari 10 pasien yang meninggal, 7 orang merupakan pasien LLA dan 3 orang pasien LMA. Pasien LLA yang meninggal dengan usia diagnosis 1-4 tahun sebanyak 2 orang, 5-9 tahun 3 orang dan 15-19 tahun 2 orang. Sementara pasien LMA yang meninggal saat usia diagnosis $1-4$ tahun sebanyak 1 orang, 5-9 tahun 1 orang dan 15-19 tahun 1 orang. Perbedaan ini mungkin karena sampel yang diambil kurang memadai untuk dapat menarik kesimpulan.

Delapan belas orang pasien tercatat belum selesai menjalani protokol terapi, tetapi tidak dapat dipastikan apakah seluruh pasien masih menjalani terapi atau menolak dan atau mengabaikan pengobatan. Menurut Sitaresmi dkk, ${ }^{27}$ menolak pengobatan memiliki definisi penolakan terhadap segala macam terapi pada kanker yang memiliki kemungkinan untuk sembuh setelah ditegakkan diagnosis, sedangkan mengabaikan pengobatan berarti melewatkan 4 minggu pengobatan atau follow up berturut-turut saat masih dalam protokol terapi. Penolakan atau pengabaian pengobatan merupakan penyebab paling sering kegagalan terapi di Indonesia. Alasan orang tua menolak atau mengabaikan pengobatan, di antaranya kekurangan finansial dan masalah transportasi menjadi kontributor utama. Namun, hal lain seperti keyakinan akan kesembuhan LLA, kekhawatiran dan pengalaman mengenai efek samping yang berat, penolakan oleh anak, serta ketidakpuasan terhadap tenaga kesehatan juga turut andil. ${ }^{27}$

Menurut Adhisty, ${ }^{7}$ pelaksanaan perawatan paliatif di RSUP dr. Sardjito masih mengalami hambatan, seperti standar perawatan yang belum ada, dokterperawat yang belum mendapatkan informasi maksimal mengenai perawatan kanker paliatif, kepribadian masing-masing klinisi, komunikasi yang berjenjang hingga waktu yang terbatas untuk melakukan diskusi. Beberapa data penelitian ini lebih baik diteliti secara prospektif dan menggunakan kuesioner. Hal tersebut untuk menghindari ketidaklengkapan rekam medis dan memperkaya serta mengembangkan data, seperti data mengenai penanganan farmakoterapi maupun non farmakoterapi, keberhasilan penanganan tanda dan gejala, serta frekuensi tanda dan gejala saat tidak di rumah sakit. 


\section{Kesimpulan}

Tanda dan gejala dengan prevalensi tertinggi adalah nyeri bagi pasien LLA dan demam bagi pasien LMA. Perawatan paliatif diperlukan terutama pada fase induksi dan maintenance I bagi pasien LLA dan fase induksi I bagi pasien LMA. Perlu ditingkatkan pengetahuan mengenai perawatan paliatif terutama pada tenaga kesehatan yang sering terlibat dalam perawatan paliatif, yaitu residen pediatrik/dokter spesialis anak/konsultan anak, perawat, dokter spesialis anestesi, ahli gizi, dan rohaniawan.

\section{Daftar pustaka}

1. World Health Organization. Health in 2015: from MDGs, Millennium Development Goals to SDGs, Sustainable Development Goals. World Health Organisation; 2015. h.204.

2. Ward E, DeSantis C, Robbins A, Kohler B \& Jemal A. Childhood and adolescent cancer statistics, 2014. CA: A Cancer J Clin 2014;64:83-103.

3. Clarke RT, Van den Bruel A, Bankhead C, Mitchell CD, Phillips B \& Thompson MJ. Clinical presentation of childhood leukaemia: a systematic review and meta-analysis. Arch Dis Child 2016;101:894-901.

4. American Cancer Society. Global cancer facts \& figures. Edisi ke-3. Am Cancer Soc 2015;(800):1-64.

5. Fakhry H, Goldenberg M, Sayer G, dkk. Health-related quality of life in childhood cancer. J Develop Behav Pediatr 2013;34:419-40.

6. World Health Organization. Cancer pain relief and palliative care in children. Geneva: World Health Organization; 1998.

7. Adhisty K. Pelayanan paliatif pada pasien kanker di RSUP Dr. Sarjito Yogyakarta. [Yogyakarta]: Universitas Gadjah Mada; 2016..

8. Keputusan Menteri Kesehatan nomor 812/Menkes/SK/ VII/2007. Kebijakan perawatan paliatif. 19 Juli 2007. Jakarta: Kepmen KemKes; 2007.

9. Clarke RT, Van den Bruel A, Bankhead C, Mitchell CD, Phillips B \& Thompson MJ. Clinical presentation of childhood leukaemia: a systematic review and meta-analysis. Arch Dis Child 2016;101:894-901.

10. Fragkandrea I, Nixon JA \& Panagopoulou P. Signs and symptoms of childhood cancer: a guide for early recognition. Am Fam Physic 2013;88:185-92.

11. Raab SO, Hoeprich PD, Wintrobe MM \& Cartwright GE. The clinical significance of fever in acute leukemia. Blood Am Soc Hematol 1960;16:1609-28.

12. Ishii E, Hara T, Mizuno Y \& Ueda K. Vincristine-induced fever in children with leukemia and lymphoma. Cancer 1988;61:660-2.

13. Rashidy F, Ragab S, Dawood A \& Temraz S. Toxic complications of treatment with 6-mercaptopurine in pediatric acute lymphoblastic leukemia. Menoufia MedJ 2015;28:411.

14. Sakata H, Nakao A, Matsuda K, dkk. Acute leukemia presenting as bone pain with normal white blood cell count. Acute MedSurg 2014;1:249.

15. Niscola P, Tendas A, Scaramucci L, dkk. Pain in malignant hematology. Expert Rev Hematol 2011;4:81-93.

16. Anghelescu DL, Faughnan LG, dkk. Neuropathic pain during treatment for childhood acute lymphoblastic leukemia. Pediatric Blood \& Cancer 2011;57:1147-53.

17. Inaba $\mathrm{H} \&$ Pui C-H. Glucocorticoid use in acute lymphoblastic leukaemia. The Lancet Oncol 2010;11:1096-6.

18. $\mathrm{PDQ}^{\circ}$ Supportive and Palliative Care Editorial Board. PDQ treatment-related nausea and vomiting. Bethesda, MD: National Cancer Institute. Updated <05/10/2017>. Diakses pada 3 Oktober 2021Didapat dari: https://www.cancer. govlaboutcancer/treatment/side-effects/nausea/nausea-hp-pdq. Accessed <04/17/2018>. [PMID: 26389491]

19. $\mathrm{PDQ}^{\circ}$ Supportive and Palliative Care Editorial Board. PDQ cancer pain. Bethesda, MD: National Cancer Institute. Updated <08/30/2017>. Diakses pada 3 Oktober 2021. Didapat dari: https://www.cancer.govlabout-cancer/treatment/ side-effects/pain/pain-hp-pdq. Accessed <04/27/2018>. [PMID: 26389387]

20. Pashankar FD, Season JH, McNamara J \& Pashankar DS. Acute constipation in children receiving chemotherapy for cancer. J Pediatr Hematol/Oncol 2011;33:e300-3.

21. Yazbeck N, Samia L, Saab R, Abboud MR, Solh H \& Muwakkit S. Effect of malnutrition at diagnosis on clinical outcomes of children with acute lymphoblastic leukemia. J Pediatr Hematol/Oncol 2016;38:107-110.

22. Fitchett G, Lyndes KA, Cadge W, Berlinger N, Flanagan E \& Misasi J. The role of professional chaplains on pediatric palliative care teams: Perspectives from physicians and chaplains. J Palliat Med 2011;14:704-7.

23. Gupta S, Antillon FA, Bonilla M, dkk. Treatment-related mortality in children with acute lymphoblastic leukemia in Central America. Cancer 2011;117:4788-95.

24. Martín-Trejo JA, Núñez-Enríquez JC, Fajardo-Gutiérrez A, dkk. Early mortality in children with acute lymphoblastic leukemia in a developing country: The role of malnutrition at diagnosis. A multicenter cohort MIGICCL Study. Leukemia \& Lymphoma. 2017;58:898-908.

25. Prucker C, Attarbaschi A, Peters C, dkk. Induction death and treatment-related mortality in first remission of children with acute lymphoblastic leukemia: A population-based analysis of the Austrian Berlin-Frankfurt-Münster Study Group. Leukemia 2009;23:1264-9.

26. Wang Y, Huang J, Rong L, Wu P, Kang M, Zhang X dkk. Impact of age on the survival of pediatric leukemia: an analysis of 15083 children in the SEER database. Oncotarget. 2016;7:83767-83774.

27. Sitaresmi MN, Mostert S, Schook RM., Sutaryo \& Veerman AJP. Treatment Refusal and Abandonment in Childhood Acute Lymphoblastic Leukemia in Indonesia: An Analysis of Causes and Consequences. Psycho-Oncology 2010;19:361-367. 